\title{
(IN)ADEQUATE CRIMINAL PROTECTION OF THE CAPITAL MARKET IN THE REPUBLIC OF SERBIA*
}

\author{
Jelena Kostić, PhD, Research Fellow \\ Institute of Comparative Law \\ Terazije 41, Belgrade, Serbia \\ j.kostic@iup.rs
}

\author{
Sanja Jelisavac Trošić, PhD, Senior Research Fellow \\ Institute of International Politics and Economics \\ Makedonska 25, Belgrade, Serbia \\ sanja@diplomacy.bg.ac.rs
}

\begin{abstract}
Regulation 596/2014/EU and Directive 2014/57/EU were adopted in order to provide adequate protection of investors and the smooth functioning of the capital market in European Union (EU). They envisage the obligations of Member States to prescribe, under national law, misdemeanor and criminal sanctions for conduct that constitutes abuses in the capital market. Their aim was to provide the same level of criminal justice protection at the level of all EU countries. As EU candidate country, the Republic of Serbia has prescribed sanctions by the Law on the Capital Market, the Law on Takeovers of Joint Stock Companies and the Law on Open-Ended Investment Funds subject to Public Offering.

Although serious abuses in the capital market of the Republic of Serbia constitute criminal offenses, in practice it seems impossible for prosecutors and courts to prove their existence. Therefore, we cannot say that there is adequate protection of investors or unhindered functioning of the capital market. Given that national courts do not recognize as valid circumstantial evidence, it is impossible to prove some of these acts without the use of specific evidentiary actions such as, for example, eavesdropping on telecommunications. However, the Criminal Procedure Code of the Republic of Serbia only provides for a limited number of criminal offenses to which such evidentiary actions can be applied. This provision does not cover offenses under the sec-
\end{abstract}

This paper was created within the two projects: "Serbian and European Law: Comparison and harmonization", Ministry of Education and Science of the Republic of Serbia, number 179031, which is implemented in the Institute of Comparative Law and "Serbia and challenges in international relations in 2020", financed by the Ministry of Education, Science, and Technological Development of the Republic of Serbia, and conducted by Institute of International Politics and Economics, Belgrade 
ondary criminal legislation and, therefore, offenses representing abuses in the capital market. In the previous period, the Securities Commission has filed several criminal charges against the perpetrators of such criminal offenses, however, the Public Prosecutor's Office has not filed any lawsuit or notified the authorized applicant on the outcome of the proceedings. Such actions could further discourage institutions authorized to monitor legitimate capital market operations from filing criminal charges against capital market abusers in the future, some of which may be related to corporate business corruption. This could certainly have a negative impact on the decisions of both existing and potential investors in the capital market.

This paper starts with the analysis of compliance of the regulations of the Republic of Serbia with Regulation 596/2014/EU and Directive 2014/57/EU, then points to the lack of provisions of the Criminal Procedure Code which provides for the limited application of special evidence in criminal proceedings. Based on this analysis the authors strive to make recommendations in order to improve the implementation of provisions that enable the suppression of criminal offenses which threaten the capital market integrity. In this way, we would like to point out that alignment with the acquis communautaire also implies the possibility of applying its standards in the territory of both candidate and EU Member States. Therefore, in order to achieve this goal, it is necessary not only to adopt new regulations, but also to harmonize the existing provisions of some other regulations which enable their implementation in the practice.

Keywords: capital market, abuses, criminal offenses, inability to prove, special evidentiary actions

\section{INTRODUCTION}

An obstacle to entering a one market can be the possibility of creation a monopoly, which can also have a negative impact on the national economy. Therefore, state intervention is required, which is reflected in the establishment of bodies responsible for maintaining competitive relations in the market. ${ }^{1}$ The same case is with the capital market. The absence of adequate norms regulating capital market enables the formation of monopolies, as well as the enrichment of individuals who possess insider information. Abovementioned, results in the creation of an unfavorable environment in the capital market. ${ }^{2}$ The issue is important not only for the economy but also for the budget. Favorable conditions in the capital market can contribute to the reduction of the budget deficit, which is influenced by the purchase of government-issued bonds. ${ }^{3}$

1 Brašić, J., Institucionalne barijere za ulazak na tržište Republike Srbije i potencijalna konkurencija [Institutional barriers to market entry of the Republic of Serbia and potential competition], Pravni zapisi, vol. 1, 2016, p. 118

$2 \quad$ Ibid., p. 127

3 Nikolić, Lj.; Mojašević, A., Organizacija finansijskih tržišta [The organizanization of the Financial Market], in: P. Dimitrijević (ed.), Zaštita ljudskih i manjinskih prava u evropskom pravnom prosoru, tematski broj Zbornika radova Pravnog fakulteta Univerziteta u Nišu, Niš, 2012, pp. 122-123 
The modern capital market is internationalized. Therefore, at the international level, there is a strong interest in combating behavior that has a negative impact on the smooth functioning of the capital market. Like any other market, the law of "supply and demand" should function smoothly. It could be disturbed by the indecent behavior of individuals, which would have a negative effect on further trade in that market. Major discrepancies may impair the functioning of the basic principles of a market economy, both nationally and internationally. ${ }^{4}$

At the European Union level, the idea of establishing a European capital market has gradually evolved, with the aim of improving capital mobility and investing in companies and infrastructure of EU member states. The aim of such action was to strengthen the financial system of the entire community. However, obstacles to the realization of this idea were the different rules and practices of national capital markets. Therefore, there was a need to harmonize practices in this area. One of the priorities was to protect investors in the capital market from the misconduct of other participants. ${ }^{5}$

Insider trading has been labeled as a criminal offense since the 1920s and in European countries only in the last few years. ${ }^{6}$ Therefore, the legal description of the offense of insider trading in European countries appears to be very similar to the solution existing in the United States. However, such a solution may present a problem in terms of proving criminal offenses. The offense of insider trading may require special evidence to be taken into consideration because of the large number of persons who hold such information. Therefore, in addition to prescribing sanctions for certain behaviors that constitute criminal offenses, it is necessary for criminal law to provide for an adequate way of proving them. In doing so, it is necessary to have evidentiary standards established by the legislation of a particular country.

In this paper we will first start with the European Union standards in the field of criminal justice protection of the integrity of the capital market. We will then analyze the compliance of the substantive criminal law provisions with them. In addition, we will highlight the problems that exist regarding the implementation of full criminal justice protection and make recommendations for its improvement.

Kostić, J., Izazovi harmonizacije krivičnopravne zaštite tržišta kapitala sa pravom Evropske unije - primer italijanskog zakonodavstva, [Challenges of harmonization with EU standards in capital market protection by criminal law-example of Italian legislation], Strani pravni život, vol. 2, 2018, p. 120

Ibid., p. 121

6 Stojanović, Z. et al, Priručnik za suzbijanje privrednog kriminaliteta $i$ korupcije [Manual on suppression of economic crimes and corruption], Ministarstvo pravde SAD, Kancelarija za međunarodnu pomoć, usavršavanje i profesionalnu obuku u pravosuđu i Misija OEBS-a u Srbiji, Beograd, 2018, p. 187 


\section{EUROPEAN STANDARDS IN THE FIELD OF CRIMINAL PROTECTION OF THE CAPITAL MARKET}

Council Directive 89/592/EEC of 13 November 1989 coordinating regulations on insider dealing did not impose an obligation on Member States to prescribe the offense of insider trading. ${ }^{7}$ Such an intention was first expressed in Directive 2003/6/EC of the European Parliament and of the Council of 28 January 2003 on insider dealing and market manipulation (market abuse). ${ }^{8}$ However, the conditions for criminal sanctioning of insider trading were created only by the adoption of Regulation No 596/2014 of the European Parliament and of the Council of 16 April 2014 on market abuse (market abuse regulation) and Directive 2014/57/ EU of the European Parliament and of the Council of 16 April 2014 on criminal sanctions for market abuse (market abuse directive). ${ }^{?}$

\subsection{Significance of the Regulation No 596/2014 on market abuse}

The Regulation No 596/2014 on market abuse defines unlawful disclosure of privileged information and manipulation of the capital market. ${ }^{10}$ In order to prevent these phenomena, and in order to protect the integrity of the capital market and its participants, certain measures have been envisaged.

This Regulation defines privileged information acquired as information of certain content that has not been published and which directly or indirectly relates to one

$7 \quad$ The Directive provides for mutual assistance through the exchange of information between national authorities responsible for overseeing transactions in the capital market, with a view to preventing and detecting irregularities in insider trading. Pursuant to the provisions of the Directive, interested parties were able, by prior agreement, to enhance cooperation with a view to establishing liability for illicit activities that threaten equal access to information for all participants in the capital market and which may constitute the commission of other offenses. The text of the Direction in English is available at: [https://rm.coe.int/CoERMPublicCommonSearchServices/DisplayDCTMContent?documentId=090000168007b0d5], accessed on 05. April 2020

8 Directive 2003/6/EC of the European Parliament and of the Council of 28 January 2003 on insider dealing and market manipulation (market abuse), Official Journal L096 12/4/2003, [https://eur-lex. europa.eu/legal-content/EN/ALL/?uri=celex\%3A32003L0006], accessed on 05. April 2020. Although the Directive did not provide an obligation for Member States to prescribe criminal sanctions for abuses in the capital market at national level, its adoption represented a significant step towards this. In accordance with its provisions, Member States are obliged to provide in their national regulations for the powers of national institutions to detect abuses in the capital market

9 Stojanović et al., op. cit. note 6, p. 187,188

10 Regulation (EU) No 596/2014 of the European Parliament and of the Council of 16 April 2014 on market abuse (market abuse regulation) and repealing Directive 2003/6/EC of the European Parliament and of the Council and Commission, Directives 2003/124/EC,2003/125(EC and 2004/72/EC, Official Journal of the European Union L 173/1, [https://eur-lex.europa.eu/legal-content/EN/TXT/ PDF/?uri=CELEX:32014R0596\&from=EN], accessed on 05. April 2020 
or more issuers or one or more financial instruments, which if published would significantly affect the price of those financial instruments or on the price of related financial instruments. Privileged information may also apply to commodity derivatives, provided that it is unpublished information that, if released directly or indirectly, would relate to one or more of those derivatives and which would then likely have a significant effect on their price. This information must be published in accordance with Union or national regulations, market rules, contracts, practices or traditions in the relevant commodity markets. According to Article 7 of the Regulation, privileged information means information relating to broadcast units or products on the market that are based on them and which have not been published. In addition, it is necessary that this information is directly or indirectly related to one or more financial instruments and which, if disclosed, would have a significant impact on the prices of those or related financial instruments. The regulation is relevant for defining the elements of the insider trading offense. Therefore, at national level, it was necessary for the definition of privileged information to be aligned with the aforementioned provision of the Regulation defining the elements of the substance of the insider trading crime.

The Regulation also stipulates when it is allowed and when not to use privileged information in the capital market. Trading on the basis of privileged information within the meaning of the Regulation means the trading of privileged information held by a particular person for the purpose of acquiring or selling on his own behalf or for the benefit of some third party of a particular financial instrument to which that information relates. In addition, it involves the use of privileged information to modify or cancel an order in respect of financial instruments to which the information relates, when the order was submitted before a person possessed the information. In accordance with Article 8 of Regulation No 596/2014, the use of privileged information involves the submission, modification or withdrawal of a purchase offer undertaken by a particular person for his own account or for the account of a third party. ${ }^{11}$ The above definition is important for determining the limits of criminal repression, because in certain situations the use of privileged information in the capital market will not be considered illegal, and therefore undertaking such activities will not be considered an element of the crime. It was therefore necessary at national level to harmonize the rules governing capital market relations with the provision of Regulation No 596/2014, which defines when the use of privileged information is permitted.

Important for defining the elements of the offense of insider trading is the understanding of the concept of unlawful disclosure of privileged information, which

11 Article 9 of the Regulation defines permitted activities 
means the communication to any other person of privileged information that one possesses, except when they are published in the ordinary course of business, profession or duty. Illegal disclosure can be perpetrated by both natural and legal persons. Illegal activity is not only the publication of privileged information contrary to the mentioned rule, but also the encouragement of other persons to publish it, if it is done by a person who knows or should know that it is privileged information. ${ }^{12}$ The Regulation does not provide for an obligation for Member States to impose criminal sanctions at national level prohibiting certain illicit activities in the capital market. However, its provisions are important for defining the elements of the substance of crimes related to abuses in the capital market. It explicitly stipulates that trading in the capital market should not be based on privileged information. In addition, it is prohibited to recommend to another person to trade on the basis of privileged information, as well as to encourage another person to trade privileged information and unlawfully publish privileged information.

Securities are valued on the capital market based on the available information. A certain number of persons have certain information, not only the managers of certain companies but also some other persons such as accountants and others. Insider information is not publicly available, and it is very difficult to determine how many people are involved because of the type of work they do. For this reason, there are authors who consider it unnecessary to impose an insider trading ban even though it is established in most developed countries. ${ }^{13}$ The same authors argue that insider information is working towards the establishment of real prices irrespective of whether it is adjusted up or down. ${ }^{14}$ However, in any case, it is essential to have adequate and timely financial information to make financial decisions. ${ }^{15}$ We therefore believe that it is nevertheless necessary to prohibit insider trading and to put in place adequate mechanisms to prevent it. However, this mechanism is not only made up of misdemeanors and criminal sanctions. Given that insider information is often available to a large number of individuals, a great deal of effort is needed to determine who made it possible for them to trade based on insider information. In fact, this is a prerequisite for the imposition of a misdemeanor or criminal sentence.

12 Article 10 of the Regulation

13 Prokopijević, M. Tržište kapitala u Srbiji [Capital market in the Republic of Serbia] (this article has been published in december 2006 in the Collection of papers of the Institute of Euroepan studies), Available at: [https://pescanik.net/wp-content/PDF/trziste_kapitala_u_srbiji.pdf], accessed on 05 . April 2020

14 Ibid.

15 Bakić, S., Tržište kapitala u Srbiji [Capital market in Serbia], Oditor, časopis za menadžment, finansije i pravo, vol. 5 , no. 3,2019 , p. 56 
The Regulation prohibits manipulation and attempted manipulation, as another type of abuse in the capital market. Manipulation means entering into a transaction, issuing a trading order or any other procedure by which a person gives or is likely to give inaccurate or misleading information regarding the supply, demand or price of a financial instrument or maintain the price of one or more financial instruments at an unusual or lower level. The regulation is important for defining the elements of the crime of capital market manipulation. According to its provisions, manipulation of the capital market will not exist if a person entering into a transaction gives a trading order or takes any other action that has been taken for legitimate reasons and is in accordance with accepted market practice established in accordance with Article 13 of the Regulation. Manipulation also means the transmission of false or misleading information or the provision of false or misleading basic information in relation to reference values, when the person who transmitted the information or provided the basic information knew or should have known that they were false or misleading. Manipulation is also considered to be any other procedures that manipulate the amount of the reference values. The regulation does not mandate Member States to impose criminal sanctions on national legislation for conduct that may be considered missuses in the capital market, but it has a significant criminal legal scope. In addition to its provisions, being of great importance for determining the elements of the offenses of insider trading and capital market manipulation, it also provides for an obligation for Member States to provide for sanctions for offenses for acting contrary to the regulations governing capital markets, as national regulations, and the powers of the competent authorities to impose such sanctions. In addition to its provisions being of great importance for determining the elements of the insider trading offenses and capital market manipulation, it also envision an obligation for Member States to provide sanctions for acting contrary to the regulations governing capital markets, as national regulations, and the powers of the competent authorities to impose such sanctions.

\subsection{Goals and recommendations of the Directive 2014/57/EU}

Recommendation for Member States of the European Union to prescribe by national legislation criminal sanctions for behaviors that violate the integrity of the capital market is laid down in the European Parliament and the Council Directive 2014/57/EU. The Directive recommended that Member States establish as criminal offenses trade based on privileged information, also for recommending or encouraging another to trade based on privileged information, where such activities were intentionally undertaken and also in more serious situations. Accordingly, Member States were required to treat as criminal offences in the national 
legislation the publication of privileged information and disclosure of privileged information to other persons. However, this does not apply to the disclosure of information as a normal part of the job and in situations where such activity may qualify as market research. ${ }^{16}$

The Directive recommended that Member States in their respective national legislations prescribe market manipulation as a criminal offense. Market manipulation activities include the execution of transactions, the issuing of a trading order, and any other procedure that gives false or misleading information regarding the supply, demand or price of financial instruments or related spot commodity contracts. Market manipulation is also considered to be any activity whereby the price of one or more financial instruments or related commodity contracts is maintained at an unusual or artificial level. However, there will be no basis for liability if the reasons why the person who made the transaction or gave a reason for trade is justified, or if the transaction or trading order is in accordance with accepted market practice in the specific trading place. Manipulation, within the provisions of the Directive, also implies the execution of a transaction, the placing of a trading orders, or any other activity or procedure affecting the price of one or more financial instruments, or a related spot contracts for goods, using fictitious contracts or any other form of fraud or scams. In addition, Member States should prescribe as an act of commission of a crime, the dissemination of information through the media, including the Internet and any other means of giving false or misleading signs in terms of supply, demand or price of a financial instrument, or related spot contract for goods at an unusual or artificial level, where the disseminators gain for themselves or for another person the benefits of disseminating specific information, as well as forwarding false or misleading information, or providing false, or misleading basic information or any other method of manipulating the calculation reference values. ${ }^{17}$

In addition to recommending Member States to prescribe those activities as criminal offenses under their national legislation, one of the recommendations is to prescribe criminal sanctions for persons assisting or inciting a person to commit a crime that violates the integrity of the capital market, as well as for a person attempting the execution. ${ }^{18}$

\footnotetext{
16 Article 4 of the Directive 2014/57/EU of the European Parliament and of the Council of 16 April 2014 on criminal sanctions for market abuse (market abuse directive), OJ L 173, 12.6.2014, p. 179189

17 Article 5 of the Directive

18 Article 6 of the Directive
} 
To trade based on privileged information, the recommendation to trade based on privileged information, as well as the market manipulation, recommendation is that national law prescribe a minimum of four years imprisonment. ${ }^{19}$ Whereas for the illegal publication of privileged information, it is recommended to be prescribed, a national sentence of at least two years imprisonment. ${ }^{20}$

The provisions of the Directive do not call into question the independence of the judiciary and differences in the organization of the judiciary at European Union level, but one of the recommendations is the training of judges, prosecutors, police, judicial staff, as well as employees in relevant institutions involved in criminal proceedings and conducting investigative actions to ensure at national level the achievement of the objectives defined by its provisions. ${ }^{21}$

The criminal legislation of the Republic of Serbia prescribes both misdemeanors and criminal offenses that distort the capital market. However, it does not appear that the necessary conditions have been created for the realization of the objectives defined by the provisions of the Directive.

\section{CRIMINAL LAW PROTECTION OF THE CAPITAL MARKET IN THE REPUBLIC OF SERBIA}

The Republic of Serbia, as a candidate country for EU membership, has harmonized its national regulations with European standards in the field of criminal protection of the integrity of the capital market. The offenses which distorts the capital market in the Republic of Serbia are prescribed by secondary criminal legislation: the Law on the Capital Market (Official Gazette of RS, No 31/2011, $112 / 2015,108 / 2016$ and 9/2020), the Law on Takeovers of Joint Stock Companies (Official Gazette of RS, No 46/2006, 107/2009, 99/2011 and 108/2016) and the Law on Open-Ended Investment Funds subject to Public Offering (Official Gazette of RS, No 73/2019).

The Law on the Capital Market specifies three offenses that violate the integrity of the capital market. These are: prohibition of market manipulation (Article 281), use and disclosure of insider information (Article 282) and unauthorized provision of investment services (Article 283). Market manipulation is defined as the act whereby an executor obtains material gain for himself or another person or harms others by completing a transaction or issuing trading orders that are given or likely to provide false or misleading information about the supply, demand or

\footnotetext{
19 Article 7, Paragraph 2 of the Directive

20 Article 6 of the Directive

21 Article 11 of the Directive
} 
price of financial instruments, or by which the entity or entities jointly maintain the price of one or more financial instruments at an unrealistic level. The act will also exist when a person concludes transactions or issues trading orders that use fraudulent practices or any other form of deception or fraud, as well as when a person disseminates information through the media, including the Internet, or by any other means transmission of untrue news or news that may be misleading about financial instruments if they knew or had to know that this information was false or misleading. The offender will get between six months and five years' imprisonment and a fine. The same article envisages a more serious form of the act that exists if the commission of the offense resulted in a significant disturbance on the regulated market or the international trading platform. The offender is sentenced to between three and eight years in prison. In addition, the possibility of punishment for attempting a crime also has been prescribed. The legal description of the offense is in line with the provisions of Directive 57/2014. The level of the sentence has also been harmonized, as well as the provision stipulating that the person attempting to commit the crime will also be punished.

The same Law prescribes the crime of using, disclosing and recommending insider information. This act exists if a person intends to gain for himself or for another person material gain or cause harm to other persons, use insider information directly or indirectly in acquiring, alienating and attempting to acquire or alienate for his own account or for the account of another person financial instruments to which that information relates, for disclosing and making available insider information to any other person, for recommending or forcing another person to acquire or dispose of the financial instruments to which that information relates based on insider information, for disclosing and making available insider information to any other person, to recommend or induce another person to acquire or dispose of the financial instruments to which that information relates based on insider information. A fine or imprisonment up to one year is prescribed for the offender. In addition to the basic one, a more serious form is also prescribed if in the committing of a criminal offense property was gained or other persons suffered property damage in the amount exceeding one million five hundred thousand dinars. The offender is punished by imprisonment for a term not exceeding three years and a fine. In addition to the basic and severe, a special form of the act is prescribed, which exists if the act was performed by a person who possesses insider information through membership in the management and supervisory bodies of the issuer or public company, participation in the capital of the issuer or public company, by accessing information obtained by performing duties on workplace, performing a professional or other duties, or through the offenses committed by that person. The offender is fined or sentenced up to three years in prison. If the 
execution of the act resulted in the material gain or damage to other persons in the amount exceeding one million five hundred thousand dinars, there will be considered as a more severe act. The offender may be punished by imprisonment for a term between six months and five years and a fine. The law also stipulates that the person who attempts to commit the offence will be punished. It seems that the basic form of the offense could have been prescribed as a misdemeanor, while it is justified that, in accordance with the provisions of Directive 57/2014, the more serious form of the offense was prescribed as a criminal act. The amount of the sentence in this case is in line with the provisions of the mentioned Directive, as well as the provision prescribing the obligation to punish the person attempting to commit the act. A special form of criminal offense is abuse of position of a responsible person, which is prescribed by Article 227 of the Criminal Code of the Republic of Serbia. ${ }^{22}$

In addition to the above crimes, the Law on the Capital Market also prescribes the criminal offense of unauthorized provision of investment services. A criminal offense exists if an individual illegally provides investment services with the intention of making a gain for himself or another person. Unauthorized provision is considered to be the provision of such services without the permission of the competent authority, and therefore it seems quite justified that in such cases the imposition of a sanction for the offense was adequate. The criminal offense of unauthorized provision of investment services is punishable by a fine or imprisonment for a term not exceeding one year. In addition to the basic one, the same provision prescribes a more serious form of act. It exists if, by undertaking an act of execution, a person obtains for himself or other persons property gain or inflicts property damage in the amount of over one million and five hundred thousand dinars. The offender was given a sentence of imprisonment of more than three years and a fine.

22 The Criminal Code of the Republic of Serbia, Official Gazette of the Republic of Serbia No 85/2005, 88/2005-ispr., 107/2005-ispr., 72/2009, 111/2009, 121/2012, 104/2013, 108/2014, 94/2016 i $35 / 2019$. The criminal offense of abuse of the responsible person position is prescribed in the group of criminal offenses against the economy and exists if the responsible person, by exercising his position or authority, exceeding the limits of his authority or by failing to perform his duty, obtains unlawful material gain for himself or another natural or legal person, unless the characteristics of another crime have been accomplished. The offender will get between three months and three years of imprisonment. In addition to the basic one, the same provision prescribes a two more serious forms of the act. The first one exist if in the committing of a criminal offense property was gained in the amount exceeding four hundred and fifty thousand dinars. The offender may be punished by imprisonment for a term between six months and five years. The second more serious form of abuse of the responsible person position exists if in the committing of crime offense property was gained in the amount exceeding million and five hundred thousand dinars. The offender may be punished by imprisonment for a term between two and ten years 
Taking into account the offenses prescribed by the Law on the Capital Market, it can be concluded that it was sufficient for the legislator to decide that only serious forms of criminal offenses should be sanctioned as criminal offenses, and that the prescribed sanctions are in line with the provisions of Directive 57/2014.

In addition to the Law on the Capital Market, the integrity of the financial market in the Republic of Serbia is also protected by the criminal law provisions prescribed by the Law on Takeover of Joint Stock Companies (Official Gazette of RS, No. 46/2006, 107/2009, 99/2011 and 108/2016). The Law prescribes three criminal offenses: offering or promising gifts, services or other benefits (Article 44), misuse of privileged information (Article 45), and publication of false information (Article 46).

The criminal offense of offering or promising gifts, services or other benefits is a special form of the criminal offense of bribery in the conduct of an economic activity. It exists if a person offers or promises a gift, services or other benefits to the shareholder after the offeror has announced the takeover bid, either directly or by advertising through the media, or if a person offers or promises gifts, services, property or other benefits for the person to accept or rejected a takeover bid. ${ }^{23}$ The offender is to be sentenced between six months and five years in prison. In addition, the same provision prescribes a criminal sanction from six months to five years of imprisonment for the person who intermediate in bribing. Therefore, if the bribery is performed in connection with the trading of shares, there will be a criminal offense of offering or promising gifts, services or other benefits.

It seems that the action of abuse of privileged information could be subsumed under the legal description of criminal offence usage, disclosing and recommending insider information, which is prescribed by the Article 282 of the Law on the Capital Market. The act of committing the crime of misuse of privileged information exists if a person commits a takeover of a Joint Stock Company by using privileged information. The same act exists if a person, in order to obtain for himself or for another person unlawful property gain, communicates to the other person privileged information or on the basis of privileged information recommends to another to acquire, buy or sell shares of the targeted company, which are traded or will be traded on organized securities market. Therefore, it appears that the regu-

23 Bribing in the conduct of an economic activity is prescribed by Article 231 and exists if a person makes, offers or promises a gift or other benefit to the person in the performance of an economic activity, concludes a contract or reaches a business agreement or provides a service or abstains from such activity or violates other duties in the exercise of economic activity to the detriment or for the benefit of the business entity for which or in which he or she works to the detriment or for the benefit of another legal or natural person, and who mediates such giving of gifts or other benefits 
lation of the mentioned act was unnecessary. Also, the existence of minor form of this act if it is committed by negligence is also unnecessary.

A special form of prohibition of manipulation in the capital market is the crime of publishing false information. Elements of this act will be materialized if a person on the regulated market or international trading platform of securities in the takeover bid publishes false information about the legal and financial position of the target company or its business opportunities, as well as other false facts that are relevant to the decision to accept the takeover bid or not to publish complete information on those facts. The offender of abovementioned will get between three months and three years of imprisonment. In addition to the basic one, a more serious form of the offense is prescribed if there is a disturbance in the regulated market, or the international trading platform of securities, due to the commission of the crime. The offender may be punished by imprisonment for a term between one and five years.

In addition to the offenses prescribed by the Law on the Capital Market and the Law on Takeover of Joint Stock Companies, the Law on Open-Ended Investment Funds subject to Public Offering also prescribes the publishing false information about open-ended investment fund with public offering. This crime will exist if someone by intention to deceive investors in rules of open-ended investment fund subject to public offering, prospectus, key information, annual or semi-annual report published false information about financial position of open-ended investment fund subject to public offering or published other false facts which are relevant to make an investment decision. The same crime will exist if someone by the intention publishing incomplete data about that facts. The offender may be punished by fine or imprisonment up to one year. The more serious form of mentioned crime will exist if in the committing of a criminal offense property was gained or other persons suffered property damage in the amount exceeding one million five hundred thousand dinars. The sanction up to three years and fine is prescribed for the offender. ${ }^{24}$ The offense of publishing false information about open-ended investment fund subject to public offering also fits within the legal description of the crime of prohibiting market manipulation. Therefore, it seems to be a redundant provision by which that act is prescribed by the Law on Open-Ended Investment Funds subject to Public Offering. In addition, above mentioned Law prescribes offense unauthorized performance of the activities of the management company and the depository. The basic form of this crime exists if someone by intention of gaining benefit for himself or another person performs the activities or a management company or the activities of a depositary without

24 Article 121 of the Law on Open-Ended Investment Funds subject to Public Offering 
authorization. The offender may be punished by a fine or imprisonment for a term not exceeding one year. More serious form of offense unauthorized performance of the activities of the management company and the depository will exist if in the committing of a criminal offense property was gained or other persons suffered property damage in the amount exceeding one million five hundred thousand dinars. The offender is to be sentenced up to three years and fine. ${ }^{25} \mathrm{We}$ consider that the regulation of the mentioned crime was unnecessary, because it could be qualified as a criminal offense fraud prescribed by Criminal Code and which will exist if someone intends to gain for himself or for another person material gain misleads or misleads him by falsely presenting or concealing the facts and thus leads him to do or not to do something to the detriment of his own or someone else's property. The offender may be punished by imprisonment for a term between six months and five years and fine. As can be noticed, the Criminal Code even prescribes a stricter punishment for the perpetrator of criminal offense of fraud. In addition, mentioned legal act prescribes one minor and two more serious forms of that crime. The minor form will exist if someone did this crime only intends to provoke the damage for some person. As can be noticed no harmful consequences are necessary for the existence of this form. The offender of this crime may be punished by imprisonment up to six months and crime. The first more serious form exists if in the committing of a criminal offense was gained or other persons suffered property damage in the amount exceeding four hundred and fifty thousand dinars. The offender is to be sentenced by imprisonment in term between one and eight years and fine. Another one more serious form will exist if in the committing of a criminal offense was gained or other persons suffered property damage in the amount exceeding million and five hundred thousand dinars. The offender may be punished by imprisonment in term between two and ten years and fine. ${ }^{26}$

Given the above, it seems that the secondary criminal legislation of the Republic of Serbia prescribes too many offenses to protect the integrity of the capital market. Prescribing a large number of crimes is neither necessary nor justified. This is often a problem when it comes to secondary criminal legislation. ${ }^{27}$ Although legal

$25 \quad$ Article 122

26 Article 208 of the Criminal Code

27 Similarly, the Law on Tax Procedure and Tax Administration of the Republic of Serbia, Official Gazette of RS, No 80/2002, 84/2002-corrigendum, 13/2003-corrigendum, 70/2003, 55/2004, 61/2005, 85/2006-other law, 62\&2006.other law, 63/2006-corrigendum of other law, 61/2007, 20/2009, 72/2009-other law, 53/2010, 101/2011, 2/2012.corrigendum, 93/2012, 47/2013, 108/2013, 68/2014, 105/2014, 91/2015-autentic interpretation, 112/2015, 15/2016, 108/2016, 30/2018, 95/2018 and 86/2019prescribes four criminal offenses, while two tax criminal offenses are prescribed by the Criminal Code. However, it seems more expedient that in the above case it was also more appropriate to prescribe certain behaviors as misdemeanors or to have their act of execution brought under 
theory often neglects the existence of secondary criminal legislation, the authors who find that moderately, rationally and realistically placed criminal legislation performs its function more successfully than too broadly set, are right on point. ${ }^{28}$ Considering that the legal description of certain offenses could be summed up under the legal description of some other, it seems quite sufficient to have two offenses: prohibition of market manipulation and using, disclosing and recommending insiders information. Therefore, it seems more appropriate that national criminal law only prescribes more serious forms of crime that violate the integrity of the capital market, which is in line with the recommendations contained in Directive 57/2014. Instead, it should focus on the possibility of proving the existence of offenses threatening the capital market, since it seems that a particular problem in practice is the proving of such offenses.

\section{PROBLEM WITH PROVING CRIMINAL OFFENSES WHICH ENDANGER CAPITAL MARKET}

According to the available data of the Securities Commission, until 2017 no final verdict was reached against the perpetrators of criminal offenses that distort the capital market. ${ }^{29}$ The prohibition of abuses in the capital market is primarily

the legal description of some other criminal offenses prescribed by the Criminal Procedure Code of the Republic of Serbia

28 Stojanović, Z., Da li je Srbiji potrebna reforma krivičnog zakonodavstva?, [Does Serbia need a criminal legislation reform], Crimen, 2/3013, p. 140. Despite the intention to reduce the number of criminal offenses provided by secondary criminal legislation, it still appears to contain a large number of crimination. However, the largest number of economic crimes is provided by secondary criminal legislation and for many of them there are almost no criminal proceedings. About that see in: Turanjanin, V. "Privredna krivična dela iz sporednog krivičnog zakonodavstva" [Economic Crimes in secondary criminal legilastion], in: Stevanović. I.; Čolović, V. (eds.), Privredna krivična dela, Institut za uporedno pravo, Institut za kriminološka i sociološka istraživanja, Beograd, 2017. p. 203 and Turanjanin V. "Krivičnopravna zaštita tržišta kapitala" [Criminal protection of the capital market], in: Godišnjak fakulteta Bezbednosti, Univerzitet u Beogradu, Fakultet bezbednosti, 2017. p. 390

29 The information was obtained from interviews with employees and members of the Securities Commission of the Republic of Serbia in April 2020. The aforementioned Institution does not have information on whether a verdict has been issued after 2017 and what are the measures taken by the public prosecutor's office against persons suspected of criminal offenses affecting the capital market in the Republic of Serbia. The Securities Commission is an independent state organization and regulator of the capital market of the Republic of Serbia. Its activities are aimed at ensuring the legal, fair and transparent functioning of the capital market, as well as protecting investors. In addition to the regulatory function, the Commission supervises participants in the capital market, stock exchanges, investment companies, broker-dealer companies, authorized banks, custodian banks, investment fund management companies, as well as the investment funds themselves. If there are facts that indicate the existence of a criminal offense, economic offense and misdemeanor, the Securities Commission shall inform the competent authority or file a criminal complaint with the competent public prosecutor's office. Information on this is available at: [http://www.sec.gov.rs/index.php/sr/], accessed on 08. April 2020 
designed to prevent certain irregularities without the use of criminal law mechanisms. Therefore, it is impossible to apply the standard of proof inherent in criminal proceedings in relation to the proof of offenses protecting the integrity of the capital market. Some authors consider overcoming of this problem by establishment a special level of evidence standards. ${ }^{30}$

Pursuant to the provisions of the Criminal Procedure Code of the Republic of Serbia, a reasonable suspicion is required in order to bring an indictment. It means the totality of facts that directly substantiate a reasonable suspicion. ${ }^{31}$ Reasonable suspicion means a set of facts that directly indicate that a person has committed a criminal offense. ${ }^{32}$ In view of the above, the existence of circumstantial evidence is not sufficient to bring an indictment in criminal law. Nevertheless, some authors consider that the definitions of the grounds of suspicion, reasonable suspicion are not quite precise and that in all cases it depends on the subjective belief of the authority conducting the proceedings and on its evaluation of evidence and indications, so it generally does not depend on the quality of the evidence. ${ }^{33}$ According to some authors, there is no reason to classify circumstantial evidence as less valuable and is thought to lead to less accurate results than direct evidence. In contrast, some studies have shown that certain types of circumstantial evidence are more accurate, and that in some situations direct evidence may lead to less accurate conclusions than circumstantial evidence. Even some research has shown that circumstantial evidence can contribute to reducing wrongful convictions to a greater extent than direct evidence. ${ }^{34}$ However, given the national legislation of the Republic of Serbia, circumstantial evidence in criminal proceedings has no significant proof value. Therefore, it seems that only the use of specific evidentiary actions is available. An obstacle to this is the provisions of the Criminal Procedure Code, which stipulates under what conditions such actions can be applied. The aforementioned regulation foresees the application of special evidentiary actions only when it comes to criminal offenses referred to in the Code. These measures may be applied to a person who is suspected of having committed any of the of-

30 Haynes, A., The burden of proof in market abuse cases, Journal of Financial Crime, vol. 20, no. 4, 2013, p. 386

31 Article 331, paragraph 1, Article 341, paragraph 1a, in conjunction with Article 338, paragraph 1, item 3 of the Criminal Procedure Code. Ibid.

32 Article 2. Points 1 and 2 of the Criminal Procedure Code

33 Grubač M.; Vasiljević T., Komentar Zakonika o krivičnom postupku, [Comment on criminal procedure code], PROJURIS, Beograd, 2014, see in: Mrčela, M.; Delost, D., Dokazni standardi u kaznenom postupku, [Evidentiary standards in criminal procedure], Policija i sigurnost, Zagreb, vol. 4, 2019, p. 423

34 Bedan, H. A.; Radebet, M., Miscarriages of Justice in Potentially Capital Cases, 40 Stan. L. Rewiew, vol. 21, no. 56/58, 1987; Blum, B., Evidence Law Convictions Based on Circumstantial Evidence, The Judges Book, vol. 3, 2019, p. 64 
fenses provided for in Article 162 of the Criminal Procedure Code, provided that no other evidence of relevance to the prosecution can be collected, or when their collecting was significantly impeded. ${ }^{35}$ In addition, the mentioned evidentiary actions may also be applied to a person suspected of preparing one of the offenses, and the circumstances of the case indicate that the offense could not otherwise be detected, prevented or proved or would cause disproportionate difficulties and great danger. ${ }^{36}$ When it comes to criminal offenses that threaten the integrity of the capital market, it is clear that in most cases evidence cannot be gathered in any other way except by the use of specific evidentiary actions. Some authors point out that the system of statutory assessment of evidence has been abandoned today, according to which laws prescribe the probative value of evidence by rules that determine how much and what kind of evidence must be collected in order for a legally decisive fact to be considered established and well founded in order to reach a decision. Therefore, the free evaluation of the evidence is left largely to the courts. ${ }^{37}$ Nevertheless, the courts adhere to the evidentiary standards defined by national law primarily to respect the presumption of innocence. Therefore, in our view, the only solution is to supplement Article 162 of the Code of Criminal Procedure by providing for the possibility of applying special evidentiary actions for crimes that threaten the integrity of the capital market. The Criminal Procedure Code provides for a limited ability to apply evidentiary actions in relation to certain criminal offenses. Thus, e.g. according to the provisions of the mentioned regulation in relation to criminal offenses: unauthorized use of a copyright and related rights, damage to computer data and programs, computer sabotage, computer fraud and unauthorized access to a protected computer, computer network and electronic data processing, only a measure of eavesdropping on telecommunications can be determined, but other evidentiary actions cannot be conducted..$^{38}$ Given the inability to prove certain activities that constitute an act of committing offenses that threaten the integrity of the capital market, the application of the mentioned measure could also be prescribed in relation to those offenses. Its application is particularly justified given the large number of persons who hold insider information, since insider trading is considered a criminal offense. In this case, it is justified to monitor both communication by telephone or other techni-

35 With regard to criminal offenses of an economic nature, Article 162 of the Criminal Procedure Code prescribes the following acts: abuse in connection with public procurement, counterfeiting of money, money laundering, as well as for offenses for which it is determined that the public prosecutor's office of special jurisdiction. However, that Article does not provide for the application of special evidentiary actions not only in the case of offenses threatening the capital market, but also for other offenses prescribed by other laws, which are also part of the secondary criminal legislation

36 Article 161 of the Criminal Procedure Code

37 Mrčela;Delost, op. cit. note 33, p. 419

38 Article 162, Paragraph 3 of the Criminal Procedure Code 
cal means, as well as surveillance of the suspect's e-mail and seizure of letters and other shipments. ${ }^{39}$

According to the Criminal Procedure Code, special evidentiary actions can also be applied to perpetrators of criminal offenses prescribed by the Law on the Organization and Jurisdiction of Government Authorities on the Suppression of Organized Crime, Terrorism and Corruption. ${ }^{40}$ However, that regulation does not apply to crimes that protect the integrity of the capital market.

Secondary criminal legislation seems to be neglected by national law when it comes to justifying the application of procedural law provisions. Therefore, consideration should be given not only to the imposition of an adequate sanction on natural and legal persons when it comes to the criminal offenses, but also for the possibility of applying that sanction. Although, in our view, it is justified that offenses containing blanket disposition should be prescribed by secondary criminal law, we believe that some legal systems are not mature enough for such an approach. The experience of the Republic of Serbia indicates that the offenses prescribed by the secondary criminal legislation are perceived as acts that are less threatening to certain social values. ${ }^{41}$ When it comes to crimes prescribed by another law, it is impossible to keep track of the number of charges and convictions for such crimes in the reports of the Statistical Office of the Republic of Serbia. They are summarized as "offenses prescribed by other laws". Our conclusion is that hyper-criminalization contributed to this, i.e. too many crimes to protect certain social values. When it comes to the integrity of the capital market, we believe that the existence of two offenses is sufficient: the prohibition of manipulation of the capital market

39 The manner of carrying out the measure of eavesdropping on telecommunications is defined in Article 166 of the Criminal Procedure Code of the Republic of Serbia

40 Article 2. of the Law on the Organization and Jurisdiction of Government Authorities on the Suppression of Organized Crime, Terrorism and Corruption (Official Gazette of RS, No. 94/2016 and $87 / 2018$ - other law) prescribes to which offenses its provisions apply. In addition, in practice exist numerous difficulties in proving of economic crimes. That requires the existence of special knowledge and skills, which requires the existence of special competencies of subjects authorized for seizure that type of crimes. More about that in: Banović, B., "Kompetentnost subjekata otkrivanja i gonjenja u funkciji efikasnog suzbijanja privrednih krivičnih dela" [Competency of entities of detection and protection in the function of efficient suppression of economic crime], in: Stevanović, I.; Čolović, V. (eds.), Privredna krivična dela, Institut za uporedno pravo, Institut za kriminološka i sociološka istraživanja, Beograd, 2017. p. 168

41 Haynes, A., in his paper Market abuse, fraud and misleading communications, Journal of Financial Crime, vol. 19, no. 3, 2012, p. 247 points out that the sanctions applied to legal entities should be such that the penalty also has some effect on the responsible persons employed by large financial investment firms. Not only does it consider that the application of sanctions would be facilitated if adequate software systems were in place to detect irregularities, the extensive use of evidentiary actions would also be of particular importance 
and the use, disclosure and recommendation of insider information. Others can either be brought under the legal description of some other crimes, or it is sufficient to prescribe such conduct as misdemeanors. The view expressed in Directive $57 / 2014$ also appears to be that adequate protection of the integrity of the capital market is provided only in situations where its functioning is seriously impaired.

\section{CONCLUSION}

Criminal offenses protecting the integrity of the capital market in the Republic of Serbia are prescribed by the secondary criminal legislation, that is, by three laws governing capital market operations. Considering that these are crimes with blanket disposition, this can be a quality solution. However, in the case of the Republic of Serbia, these laws prescribe a large number of criminal offenses. Some of them may have been prescribed as misdemeanors and others may have been subject to a legal description of pre-existing offenses. Thus, e.g. the criminal act of unauthorized provision of investment services could be prescribed as a violation of the Law on the Capital Market. The criminal offense of offering or promising gifts, services or other benefits prescribed by Article 45 of the Law on Takeovers of Joint Stock Companies could be subject to the statutory description of the criminal offense of bribery in commercial activities prescribed by the Criminal Procedure Code of the Republic of Serbia. In addition, the crime of misuse of privileged information prescribed by Article 45 of the mentioned Law could also be subject to the legal description of the offense of using, disclosing and recommending insider information, which is prescribed by Article 282 of the Law on the Capital Market. The criminal offense of publishing false information prescribed by Article 46 of the Law on Takeovers of Joint Stock Companies could be subject to the legal description of the criminal offense of prohibition of market manipulation, which is prescribed by Article 281 of the Law on the Capital Market. The same could apply to the criminal offense of advertising prospectuses with false information, which is regulated by the Law on Open-Ended Investment Funds subject to Public Offering.

Concerning the level of compliance of national regulations prescribing criminal offenses protecting the integrity of the capital market in the Republic of Serbia with Directive 57 of 2014, it can be concluded that they are largely in compliance with the mentioned Directive with regard to penalties prescribed for more serious conduct which impair the integrity of the capital market. In addition, the obligation to punish persons who attempt to commit a crime as well as persons who incite and assist in their commission is prescribed. Punishment of legal entities is possible on the basis of the Law on the Liability of Legal Entities for Criminal 
Offences, the application of which is of particular importance in relation to the protection of the integrity of the capital market.

However, it seems necessary to amend the criminal law provisions governing business in the capital market in order to narrow the criminal zone and, therefore, to make it more effective. However, a much bigger problem in practice is the inability to prove offenses that threaten the integrity of the capital market. According to the Securities Commission of the Republic of Serbia, no convictions have certainly been issued against persons who have been prosecuted on suspicion of having committed crimes that violate the integrity of the capital market, by 2017 . In addition, they have not been notified, by the competent public prosecutor's offices, of the proceedings against persons for whom criminal charges were filed in a later period. One of the reasons for this may be the lack of evidence when it comes to particular offenses, such as the criminal offense of using, disclosing and recommending insider information provided for in Article 282 of the Law on the Capital Market. Although some authors believe that criminal sanctioning of insider trading is not justified, we believe that it is still necessary. Breaking the confidence in the capital market can cause major problems in the financial market. However, because of the large number of insiders who use insider information, it is often not possible to determine which person made such information available to others. Our legislation does not recognize the possibility of using circumstantial evidence, but because of the evidentiary standards laid down in the Criminal Procedure Code of the Republic of Serbia, requires solely the use of direct evidence, which is judged on the basis of the freedom of judicial belief. In relation to the offenses prescribed by the laws governing the business in the capital market, it is not possible to apply special evidentiary actions, which include the eavesdropping on telecommunications. Therefore, it seems that the most acceptable solution, when it comes to proving crimes that threaten the integrity of the capital market, would be justify to extend the application of special evidentiary acts to the offenses prescribed by the laws governing the capital market through the Criminal Procedure Code. Bearing in mind that we believe that the existence of criminal offenses is a prohibition of manipulation on the capital market and the use, disclosure and recommendation of insider information, Article 162 of the Criminal Code could cover these offenses as well. However, both in legal theory and in practice, they appear to be unjustifiably neglected in relation to the acts prescribed by the Criminal Code as well as other acts prescribed by the secondary criminal legislation. In addition, in practice is present a rare application of crimes prescribed by secondary criminal legislation in general. Bearing in mind that most of them are economic crimes, the reason for that could be a lack of public prosecutors and judges knowledge in economy field and company law. Considering the complex- 
ity of the phenomenology of economic crime their knowledge in this area should be continuously improved.

\section{REFERENCES}

\section{BOOKS AND ARTICLES}

1. Bakić, S., Tržište kapitala u Srbiji [Capital market in Serbia], Oditor, časopis za menadžment, finansije i pravo, vol. 5, no. 3, 2019, pp. 53-64

2. Bedan, H. A.; Radebet, M., Miscarriages of Justice in Potentially Capital Cases, 40 Stan. L. Rewiew, vol. 21, no. 56/58, 1987

3. Banović, B., "Kompetentnost subjekata otkrivanja i gonjenja u funkciji efikasnog suzbijanja privrednih krivičnih dela" [Competency of entities of detection and protection in the function of efficient suppression of economic crime], in: Stevanović, I.; Čolović, V. (eds.), Privredna krivična dela, Institut za uporedno pravo, Institut za kriminološka i sociološka istraživanja, Beograd, 2017, pp. 167-185

4. Blum, B., Evidence Law Convictions Based on Circumstantial Evidence, The Judges Book, vol. 3, 2019, pp. 63-69

5. Brašić, J. „Institucionalne barijere za ulazak na tržište Republike Srbije i potencijalna konkurencija " [Institutional barriers to market entry of the Republic of Serbia and potential competition], Pravni zapisi, vol. 1, 2016, pp. 117-133

6. Grubač M.; Vasiljević T., Komentar Zakonika o krivičnom postupku, [Comment on criminal procedure code], PROJURIS, Beograd, 2014

7. Haynes, A., in his paper Market abuse, fraud and misleading communications, Journal of Financial Crime, vol. 19, no. 3, 2012, pp. 234-254

8. Haynes, A., The burden of proof in market abuse cases, Journal of Financial Crime, vol. 20, no. 4, 2013, pp. 365-392

9. Kostić, J. "Izazovi harmonizacije krivičnopravne zaštite tržišta kapitala sa pravom Evropske unije - primer italijanskog zakonodavstva", [Challenges of harmonization with EU standards in capital market protection by criminal law-example of Italian legislation], Strani pravni život, vol. 2, 2018, 113-127

10. Mrčela, M.; Delost, D., Dokazni standardi u kaznenom postupku, [Evidentiary standards in criminal procedure], Policija i sigurnost, Zagreb, vol. 4, 2019, pp. 417-435

11. Nikolić, Lj.; Mojašević, A. „Organizacija finansijskih tržišta“, [The organizanization of the Financial Market], in: Dimitrijević, P. (ed.), Zaštita ljudskih i manjinskih prava u evropskom pravnom prosoru, tematski broj Zbornika radova Pravnog fakulteta Univerziteta u Nišu, pp. $113-128$

12. Stojanović, Z., Da li je Srbiji potrebna reforma krivičnog zakonodavstva?, [Does Serbia need a criminal legislation reform], Crimen, vol. 2, no. 3013, pp. 119-143

13. Stojanović, Z. et al, Priručnik za suzbijanje privrednog kriminaliteta i korupcije [Manual on suppression of economic crimes and corruption], Ministarstvo pravde SAD, Kancelarija za međunarodnu pomoć, usavršavanje i profesionalnu obuku u pravosuđu i Misija OEBS-a u Srbiji, Beograd, 2018 
14. Turanjanin V. "Krivičnopravna zaštita tržišta kapitala" [Criminal protection of the capital market], in: Godišnjak fakulteta Bezbednosti, Univerzitet u Beogradu, Fakultet bezbednosti, 2017, pp. 367-392

15. Turanjanin, V. "Privredna krivična dela iz sporednog krivičnog zakonodavstva" [Economic Crimes in secondary criminal legilastion], in: Stevanović, I.; Čolović, V. (eds.), Privredna krivična dela, Institut za uporedno pravo, Institut za kriminološka i sociološka istraživanja, Beograd, 2017, pp. 203-213

\section{EU LAW}

1. Council Directive 89/592/EEC of 13 November 1989

2. Directive 2003/6/EC of the European Parliament and of the Council of 28 January 2003 on insider dealing and market manipulation (market abuse), [2003] OJ L096 12/4/2003

3. Regulation (EU) No 596/2014 of the European Parliament and of the Council of 16 April 2014 on market abuse (market abuse regulation) and repealing Directive 2003/6/EC of the European Parliament and of the Council and Commission, Directives 2003/124/ EC,2003/125, EC and 2004/72/EC, OJ L 173/1

4. Directive 2014/57/EU of the European Parliament and of the Council of 16 April 2014 on criminal sanctions for market abuse (market abuse directive), [2014] OJ L 173

\section{LIST OF NATIONAL REGULATIONS}

1. The Criminal Code of the Republic of Serbia, Official Gazette of RS No 85/2005, 88/2005ispr., 107/2005-ispr., 72/2009, 111/2009, 121/2012, 104/2013, 108/2014, 94/2016 I $35 / 2019$

2. The Criminal Procedure Code, Official Gazette of RS No 72/2011, 101/2011, 121/2012, 32/2013, 55/2014 i 35/2019

3. The Law on Open-Ended Investment Funds subject to Public Offering, Official Gazette of RS No 73/2019

4. The Law on the Capital Market, Official Gazette of RS No 31/2011, 112/2015, 108/2016 and $9 / 2020$

5. The Law on the Organization and Jurisdiction of Government Authorities on the Suppression of Organized Crime, Terrorism and Corruption, Official Gazette of RS No. 94/2016, 87/2018-other law

6. The Law on Takeovers of Joint Stock Companies, Official Gazette of RS No 46/2006, 107/2009, 99/2011 and 108/2016

7. The Law on Tax Procedure and Tax Administration of the Republic of Serbia, Official Gazette of RS, No 80/2002, 84/2002-corrigendum, 13/2003-corrigendum, 70/2003, 55/2004, 61/2005, 85/2006-other law, 6282006.other law, 63/2006-corrigendum of other law, 61/2007, 20/2009, 72/2009-other law, 53/2010, 101/2011, 2/2012.corrigendum, 93/2012, 47/2013, 108/2013, 68/2014, 105/2014, 91/2015-autentic interpretation, $112 / 2015,15 / 2016,108 / 2016,30 / 2018,95 / 2018$ and $86 / 2019$ 


\section{WEBSITE REFERENCES}

1. Prokopijević, M. Tržište kapitala u Srbiji [Capital market in the Republic of Serbia] (this article has been published in december 2006 in the Collection of papers of the Institute of Euroepan studies), Available at: [https://pescanik.net/wp-content/PDF/trziste_kapitala_u_ srbiji.pdf], accessed on 05. April 2020, pp. 1-20 